\title{
Article \\ Microstructure, Durability and Mechanical Properties of Mortars Prepared Using Ternary Binders with Addition of Slag, Fly Ash and Limestone
}

\author{
Javier Ibáñez-Gosálvez ${ }^{1}$, Teresa Real-Herraiz ${ }^{2}$ and José Marcos Ortega ${ }^{1, *(D)}$ \\ 1 Departamento de Ingeniería Civil, Universidad de Alicante, Ap. Correos 99, 03080 Alicante, Spain; \\ javier.ibanez@ua.es \\ 2 Instituto de Matemática Multidisciplinar, Universidad Politécnica de Valencia, Camino de Vera s/n, \\ 46022 Valencia, Spain; tereaher@upv.es \\ * Correspondence: jm.ortega@ua.es; Tel.: +34-96-5903-400 (ext. 2470)
}

check for

updates

Citation: Ibáñez-Gosálvez, J.; Real-Herraiz, T.; Ortega, J.M.

Microstructure, Durability and

Mechanical Properties of Mortars

Prepared Using Ternary Binders with

Addition of Slag, Fly Ash and

Limestone. Appl. Sci. 2021, 11, 6388.

https://doi.org/10.3390/app11146388

Academic Editors: Joan Formosa Mitjans and Jessica Giró Paloma

Received: 6 June 2021

Accepted: 1 July 2021

Published: 10 July 2021

Publisher's Note: MDPI stays neutral with regard to jurisdictional claims in published maps and institutional affiliations.

Copyright: (c) 2021 by the authors. Licensee MDPI, Basel, Switzerland. This article is an open access article distributed under the terms and conditions of the Creative Commons Attribution (CC BY) license (https:/ / creativecommons.org/licenses/by/ $4.0 /)$.

\begin{abstract}
In order to improve the contribution to sustainability of cement production, several strategies have been developed, such as the incorporation of additions as clinker replacement. Regarding the production of commercial cements with additions, those made with binary binders are mostly produced. However, the use of ternary binders for manufacturing commercial cements is still very low, at least in Spain, and they could also be an adequate solution for producing eco-friendly cements. The objective of this research is to study the effects in the long term produced by ternary binders which combine the additions of blast furnace slag, fly ash and limestone in the microstructure, durability and mechanical performance of mortars, compared to mortars without additions and mortars made with binary binders. The ternary and binary binders accomplished the prescriptions for a cement type CEM II/B. The microstructure was characterized using mercury intrusion porosimetry, electrical resistivity and differential thermal analysis. Absorption after immersion, diffusion coefficient, mechanical strengths and ultrasonic pulse velocity were studied. The best performance was noted for ternary binder with both slag and fly ash, probably produced by the synergetic effects of slag hydration and fly ash pozzolanic reactions. These effects were more noticeable regarding the compressive strength.
\end{abstract}

Keywords: ternary binders; eco-friendly cements; additions; ground granulated blast furnace slag; fly ash; limestone; sustainability; microstructure; mechanical properties; durability

\section{Introduction}

At present, to lessen the greenhouse gases emissions produced by the most contaminant industrial sectors is an important field of research [1-4]. In this topic, the construction sector and the cement industry in particular have put into practice several strategies for becoming less pollutant, in order to contribute to the global sustainable development goals, which aim to reduce global warming. Several of these strategies are related to the components of cement-based materials, such as the use of supplementary cementitious materials, recycled or lightweight aggregates, among others, as well as the combination of them, in order to develop more eco-friendly materials [5-7].

Regarding supplementary cementitious materials (SCMs), they are key components of sustainable, low carbon footprint cements, replacing partially or totally clinker [8,9]. The use of these eco-friendly cements presents several benefits [9-13]. Firstly, these cements contribute to reduce $\mathrm{CO}_{2}$ emissions produced by the cement industry, because the SCMs replace a proportion of clinker [8,9], then a lower amount of this component is required. In addition, the most popular SCMs are residues produced in other industrial sectors. Therefore, their reutilization in cement production also causes advantages from an ecological point of view. Furthermore, it has been observed that several SCMs improve the 
performance of cement-based materials, so their influence are still today a relevant field of research [9,14-17].

Among the different SCMs, it is important to highlight the active additions, such as fly ash and ground granulated blast furnace slag. In relation to slag, the development of their hydration reactions produces the formation of additional CSH phases, increasing the microstructure refinement [18] and improving the materials' properties $[19,20]$. Fly ash addition shows comparable influence in the pore network and service performance of cement-based materials, although this addition has pozzolanic activity, being capable of reacting with portlandite [15], formed as a product of clinker hydration. As a consequence of the pozzolanic reactions development, new hydrated phases are produced, making the microstructure of the material more dense $[9,15]$. On the other hand, there are additions without hydraulic or pozzolanic activity, which are also used for replacing clinker in cement production. One of the most popular is limestone, which has mainly a filler effect in cement-based materials, improving their pore size distribution, as well as their fresh and hardened properties [21-23].

In relation to the production of commercial cements with SCMs, those made with binary binders, incorporating one addition as a clinker replacement, are mostly produced nowadays. Nevertheless, the use of ternary binders, in which clinker is partially replaced by two additions, for manufacturing commercial cements is very low, at least in Spain. Therefore, to explore the performance of mortars and concretes prepared using cements made with ternary binders [21,24-26], focused on their application for commercial cements production, could be a promising research field for providing more solutions to improve the sustainability of the cement industry. In addition, the synergetic effects of combining two additions could entail an improvement of the behavior of these cement-based materials made using ternary binders [27-30].

Therefore, the objective of this research is to study the effects in the long term produced by ternary binders which combine the additions of ground granulated blast furnace slag, fly ash and limestone in the microstructure, durability-related parameters and the mechanical performance of mortars. Those additions were chosen because they are the most used in the production of blended commercial cements in Spain. In order to facilitate the real application of these results by cement manufacturers, the prepared ternary binders verified the prescriptions for a standardized commercial cement type CEM II/B-M, according to Spanish and European standard UNE-EN 197-1 [31]. The behavior of mortars made with ternary binders was compared to that observed for reference mortars prepared using ordinary Portland cement without additions, as well as with other mortars made with binary binders, which incorporated only one of the studied additions as the clinker replacement.

\section{Materials and Methods}

\subsection{Materials and Sample Preparation}

The tests were performed on mortars, which were prepared with different binders. First of all, reference mortars were made with ordinary Portland cement without additions, CEM I 42.5 R (Spanish and European standard UNE-EN 197-1 [31]), and they were named as REF in the presentation of the results.

In addition, mortars prepared with three ternary binders were analyzed. The first one, designated as SL, incorporated 15\% (in weight) ground granulated blast furnace slag and $15 \%$ limestone as additions, replacing cement CEM I $42.5 \mathrm{R}$. The second one was named as SF, in which the abovementioned CEM I 42.5 was partially substituted by $15 \%$ ground granulated blast furnace slag and 15\% fly ash. The third ternary binder was designated as FL and the cement CEM I $42.5 \mathrm{R}$ was replaced in part by $15 \%$ fly ash and $15 \%$ limestone additions.

On the other hand, three binary binders were also studied in which $30 \%$ (in weight) of the cement CEM I $42.5 \mathrm{R}$ was replaced by one of the additions used for preparing the abovementioned ternary binders. These binary binders were named as L, S and F, 
containing 30\% limestone, ground granulated blast furnace slag and fly ash, respectively. In order to facilitate the comprehension of the meaning of the different designations established for the binders, they are compiled in Table 1.

Table 1. Designation of the mortars studied and percentage (in weight) of CEM I and additions.

\begin{tabular}{ccccc}
\hline Designation & CEM I 42.5 R & Limestone & Blast Furnace Slag & Fly Ash \\
\hline REF & $100 \%$ & - & - & - \\
L & $70 \%$ & $30 \%$ & - & - \\
S & $70 \%$ & - & $30 \%$ & - \\
F & $70 \%$ & - & - & $30 \%$ \\
SL & $70 \%$ & $15 \%$ & $15 \%$ & - \\
SF & $70 \%$ & - & $15 \%$ & $15 \%$ \\
FL & $70 \%$ & $15 \%$ & - & $15 \%$ \\
\hline
\end{tabular}

The additions of fly ash, ground granulated blast furnace slag and limestone verified the prescriptions of the standard UNE-EN 197-1 [31] for being used in the production of commercial cements. These additions were provided by the company Cementos Portland Valderrivas (Spain) and they are currently used in the production of the blended cements manufactured by this company. The prepared binders accomplished the prescriptions for a standardized commercial cement type CEM II/B, defined by the standard UNE-EN 197-1 [31]. The reason for choosing that cement type is because the cements type II [31] are nowadays the most produced in Spain, so this could facilitate a wider possible real application of the results obtained in this research.

The specimens of all the binders studied were prepared with water to binder ratio 0.5. Fine aggregate was used according to the standard UNE-EN 196-1 [32] and the aggregate to cement ratio was 3:1 for all the mortar series.

Three different types of specimens were prepared. On one hand, two cylindrical specimens were made, a first type with dimensions $10 \mathrm{~cm}$ diameter and $22 \mathrm{~cm}$ height and a second one with dimensions $5 \mathrm{~cm}$ diameter and $6 \mathrm{~cm}$ height. Moreover, prismatic samples with dimensions $4 \mathrm{~cm} \times 4 \mathrm{~cm} \times 16 \mathrm{~cm}$ were also prepared.

During their first $24 \mathrm{~h}$, all specimens were kept in chamber with $95 \%$ relative humidity $(\mathrm{RH})$ and $20{ }^{\circ} \mathrm{C}$ temperature. After that time, they were de-molded and the samples were kept in an optimum laboratory condition $\left(20^{\circ} \mathrm{C}\right.$ and $\left.100 \% \mathrm{RH}\right)$ until the testing age. This condition consisted of storing the specimens in hermetically sealed containers, which contained distilled water in their bottom part for achieving a $100 \%$ relative humidity environment. The mortar samples were placed into the containers avoiding contact with water using a rack beyond the water level. In addition, these containers were kept in a chamber with a controlled temperature $20^{\circ} \mathrm{C}$. The dimensions of the hermetically sealed containers used were $325 \times 265 \times 150 \mathrm{~mm}$. Finally, the tests were performed at 28 and 250 hardening days.

\subsection{Mercury Intrusion Porosimetry}

Mercury intrusion porosimetry allows getting data about the pore network of materials [33-35]. Here, the porosimetry test was performed using a Poremaster-60 GT porosimeter manufactured by Quantachrome Instruments (Boynton Beach, FL, USA). The specimens were oven-dried at $50{ }^{\circ} \mathrm{C}$ during $48 \mathrm{~h}$ before the test. The results analyzed in this research were total porosity and pore size distribution. The pore size distribution was analyzed taking into account the following intervals: $<10 \mathrm{~nm}, 10-100 \mathrm{~nm}, 100 \mathrm{~nm}$ to $1 \mu \mathrm{m}$, $1-10 \mu \mathrm{m}, 10 \mu \mathrm{m}$ to $0.1 \mathrm{~mm}$, and $>0.1 \mathrm{~mm}[36,37]$. Two measurements were made on each type of mortar at both hardening ages studied. The samples tested were pieces taken from cylindrical specimens with $5 \mathrm{~cm}$ diameter and $6 \mathrm{~cm}$ height. 


\subsection{Electrical Resistivity}

The electrical resistivity provides information related to microstructure and pore connectivity in cement-based materials [38,39]. In this work, the non-destructive Wenner four-point test was used to obtain the resistivity of the mortars, according to the Spanish standard UNE 83988-2 [40]. This parameter was measured using a Proceq analyser on cylinders with $22 \mathrm{~cm}$ height with $10 \mathrm{~cm}$ diameter at different ages until 250 days. Three cylinders were tested for each mortar type and four measurements were made per sample at each testing age.

\subsection{Differential Thermal Analysis}

The differential thermal analyses were performed using a simultaneous TG-DTA model TGA/SDTA851e/SF/1100 from Mettler Toledo, which allows working from room temperature to $1100{ }^{\circ} \mathrm{C}$. The heating ramp selected was $20^{\circ} \mathrm{C} / \mathrm{min}$ up to $1000{ }^{\circ} \mathrm{C}$ in $\mathrm{N}_{2}$ atmosphere. The area of portlandite peak was studied and it was determined from the curve weight derivate versus temperature obtained for each mortar type. Three measurements were made on each binder at 28 and 250 days. The powder samples tested with this technique were obtained from milling pieces taken from cylinders with dimensions $5 \mathrm{~cm}$ diameter and $6 \mathrm{~cm}$ height.

\subsection{Water Absorption}

The absorption after immersion was determined following the procedure described in the ASTM Standard C642-06 [41]. Six pieces taken from cylinders with dimensions $5 \mathrm{~cm}$ diameter and $6 \mathrm{~cm}$ height were tested for each binder at 28 and 250 days.

\subsection{Steady-State Chloride Diffusion Coefficient}

The steady-state chloride diffusion coefficient was determined from the electrical resistivity of the water-saturated samples. The resistivity was obtained using the procedure described in Section 2.3. Samples were saturated for $24 \mathrm{~h}$ according to the standard ASTM C1202-12 [42]. For each binder, three different cylinders with $22 \mathrm{~cm}$ height and with $10 \mathrm{~cm}$ diameter were tested at 28 and 250 days. At each age, four measurements were made per sample. Finally, the steady-state diffusion coefficient was obtained using the following equation [43]:

$$
\mathrm{D}_{\mathrm{S}}=\frac{2 \times 10^{-10}}{\rho}
$$

where: $D_{s}$ is the chloride steady-state diffusion coefficient through the sample $\left(\mathrm{m}^{2} / \mathrm{s}\right)$ and $\rho$ is the electrical resistivity of the specimen $(\Omega \cdot \mathrm{m})$.

\subsection{Mechanical Strengths}

The compressive and flexural strengths were determined according to the Spanish and European standard UNE-EN 1015-11 [44]. Three different prismatic samples with dimensions $4 \times 4 \times 16 \mathrm{~cm}$ were tested for each one of the analyzed binders at 28 and 250 hardening days.

\subsection{Ultrasonic Pulse Velocity}

The ultrasonic pulse velocity (UPV) gives information about the mechanical characteristics of the material, as well as about the presence of defects and cracks. This parameter was determined according to the procedure described in the standard UNE-EN 12504-4 [45] at several ages up to 250 hardening days. The test consisted of measuring the propagation time of the ultrasonic waves along the longest dimension of the specimen $(160 \mathrm{~mm})$ using direct transmission. The equipment used was a Pundit Lab model manufactured by Proceq (Schwerzenbach, Switzerland). Contact transducers emitting ultrasonic pulses at $54 \mathrm{kHz}$ were coupled to the end sides of the specimens using a coupling agent. The ultrasonic pulse velocity was calculated from the propagation time and the length of the sample. 
Three prismatic samples with dimensions $4 \times 4 \times 16 \mathrm{~cm}$ were tested for each binder and three determinations were made per sample at each studied age.

\section{Results}

\subsection{Mercury Intrusion Porosimetry}

In relation to the mercury intrusion porosimetry technique, the results of total porosity are depicted in Figure 1. As can be observed, at 28 hardening days the lowest values of this parameter corresponded to the REF and $\mathrm{S}$ series. At the same age, the mortars made with ternary binders SL and SF showed slightly higher total porosities than those noted for the REF and S mortars. On the other hand, the greatest total porosities at 28 days were observed for binary mortars L and F and for the ternary binder FL. Scarce changes were observed in total porosity values between 28 and 250 days for the majority of mortars studied, although a slight reduction in this parameter was observed for the F mortars.

Total porosity

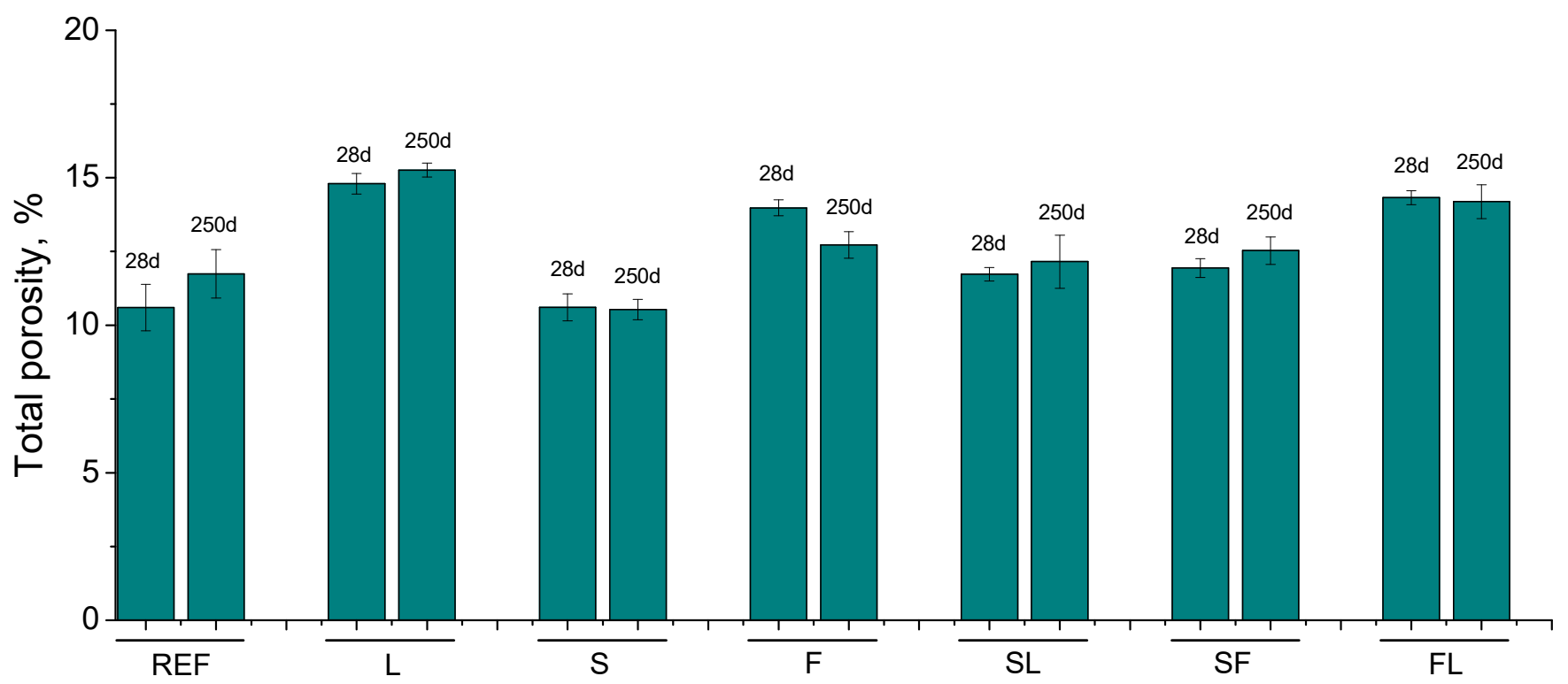

Figure 1. Total porosity results noted for the analyzed binders.

Regarding the pore size distributions, they are represented in Figure 2. At 28 hardening days, the percentages of pores with diameters lower than $100 \mathrm{~nm}$ (pore ranges $<10 \mathrm{~nm}$ and $10-100 \mathrm{~nm}$ ) were relatively similar for all studied mortars. However, at that age, binary and ternary binders with fly ash and ground granulated blast furnace slag generally presented higher relative volume of pores with sizes in the range $<10 \mathrm{~nm}$, especially for the SF series. At 250 days, an increase of those finer pores for all the studied mortars was observed, showing a higher pore refinement of the F and FL series. Finally, the less refined pore network corresponded to the L mortars along the time period studied. 


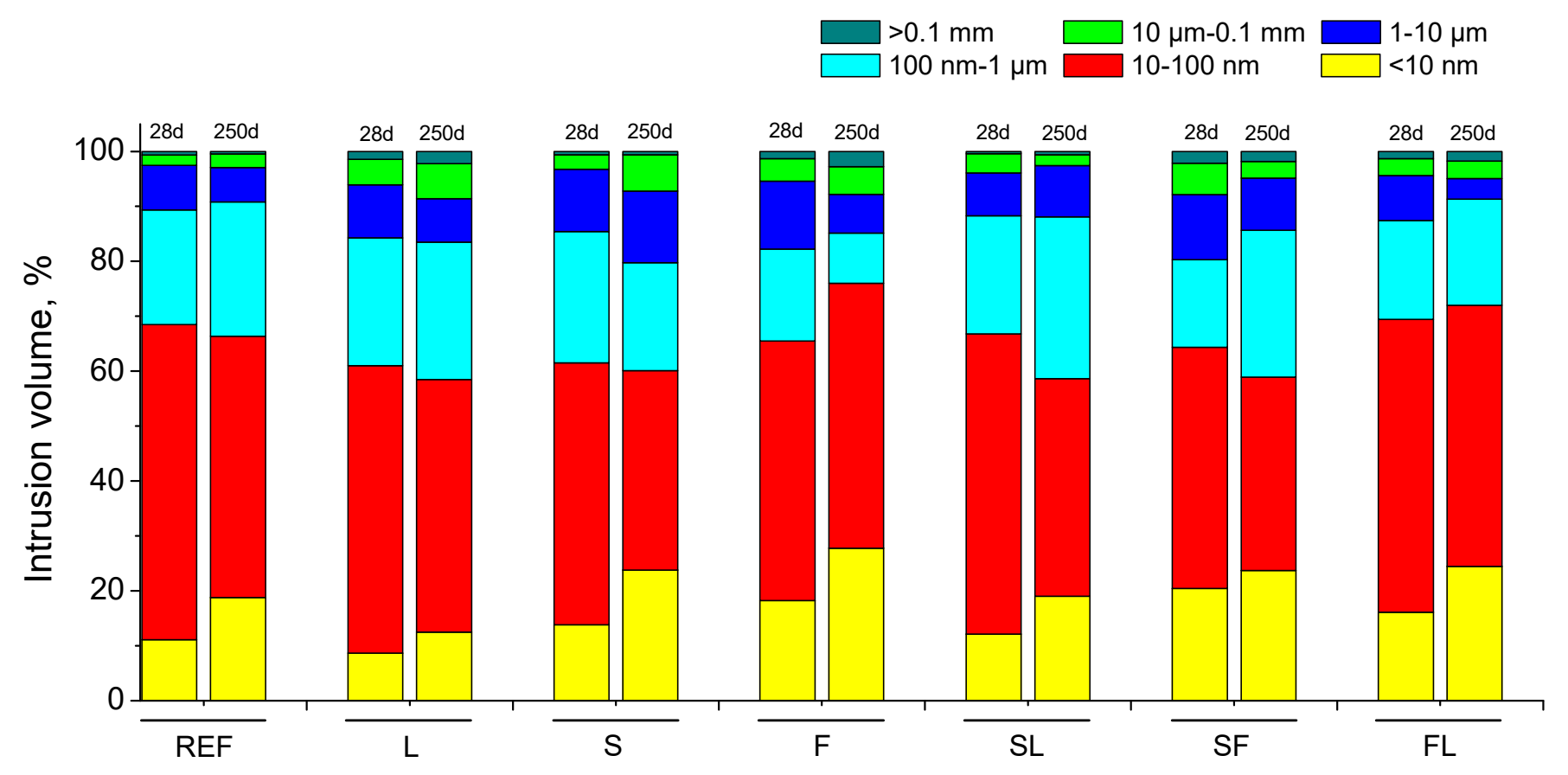

Figure 2. Pore size distributions obtained for the different types of mortar studied.

\subsection{Electrical Resistivity}

The electrical resistivity results are depicted in Figure 3. The majority of the analyzed mortars showed an increasing tendency of this parameter during the studied time period. At early ages, the highest electrical resistivity values were noted for binary and ternary binders with slag (S, SL and SF series). On the other hand, this parameter noticeably increased with time for binary and ternary binders with fly ash (F, SF and FL), showing the greatest values of electrical resistivity at 250 days. The resistivity also rose with age for $\mathrm{S}$ and SL mortars, although their values at the end of the studied time period were lower than those noted for binders with fly ash. Finally, the lowest resistivity values were noted for the REF and L mortars, and they hardly changed from 28 to 250 days.

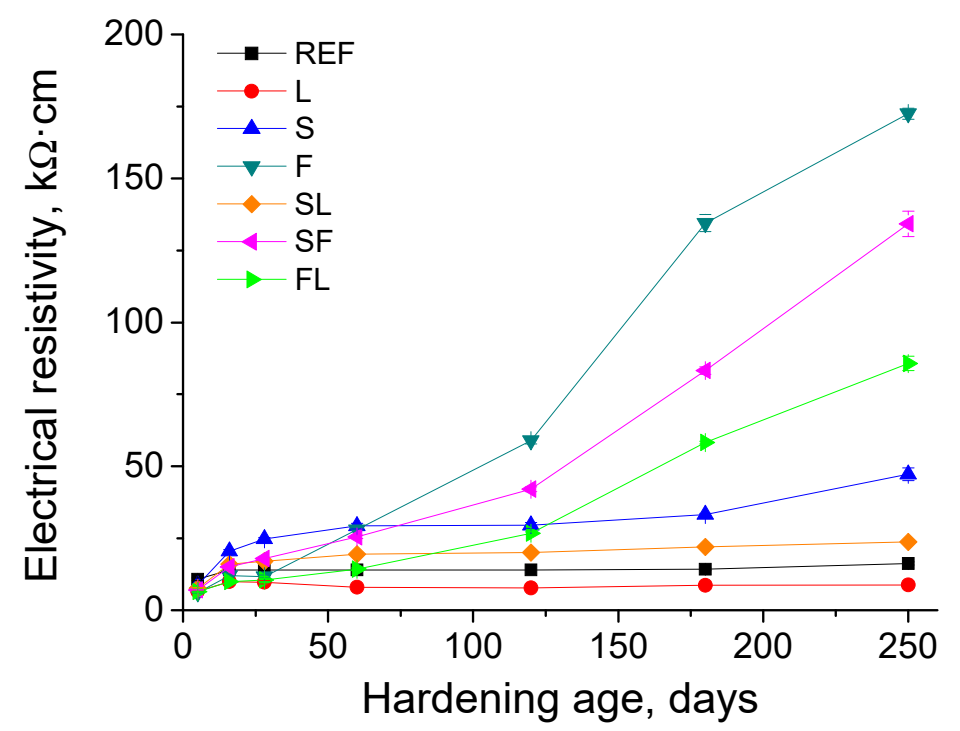

Figure 3. Evolution of the electrical resistivity for the different binders studied. 


\subsection{Differential Thermal Analysis}

Regarding the differential thermal analyses performed, the derivate of weight versus temperature curves and the areas of the portlandite peak obtained for the studied binders at 28 and 250 days can be observed in Figures 4 and 5, respectively. In view of these results, it is interesting to highlight the reduction of this area in specimens with fly ash (F, FL and SF series), which would be indicative of the portlandite consumption due to the development of fly ash pozzolanic reactions.

\section{8 days}

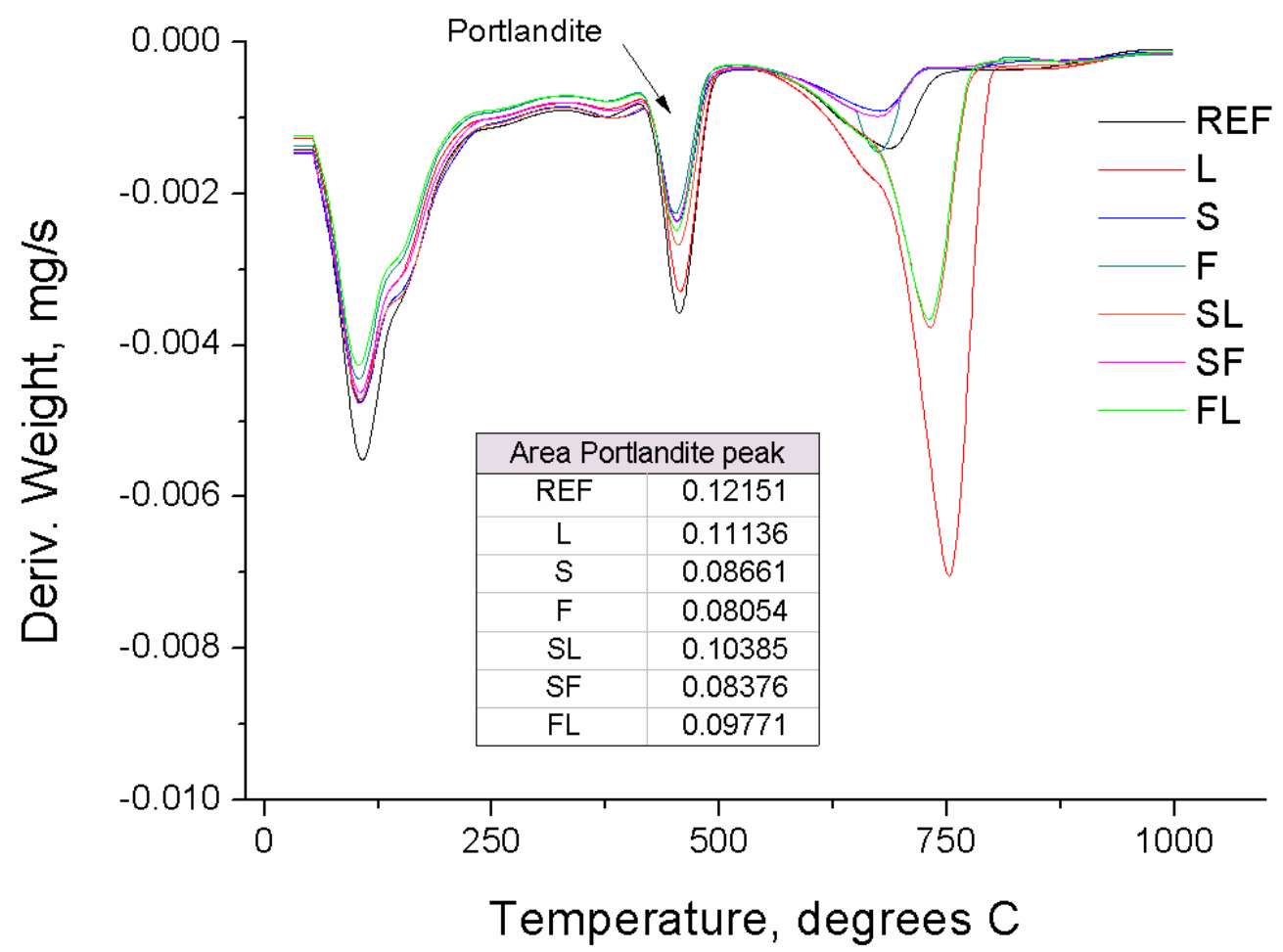

Figure 4. Derivate of weight versus temperature curves and areas of the portlandite peak obtained at 28 hardening days for different binders studied.

\subsection{Water Absorption}

The results of water absorption after immersion are shown in Figure 6. This parameter was relatively similar at 28 and 250 hardening days for all the mortars studied. Specimens with ternary binders showed a slight reduction of the absorption after immersion between 28 and 250 days. At that last age studied, this parameter was higher for the L series, compared to the rest of the studied binders. 


\section{0 days}

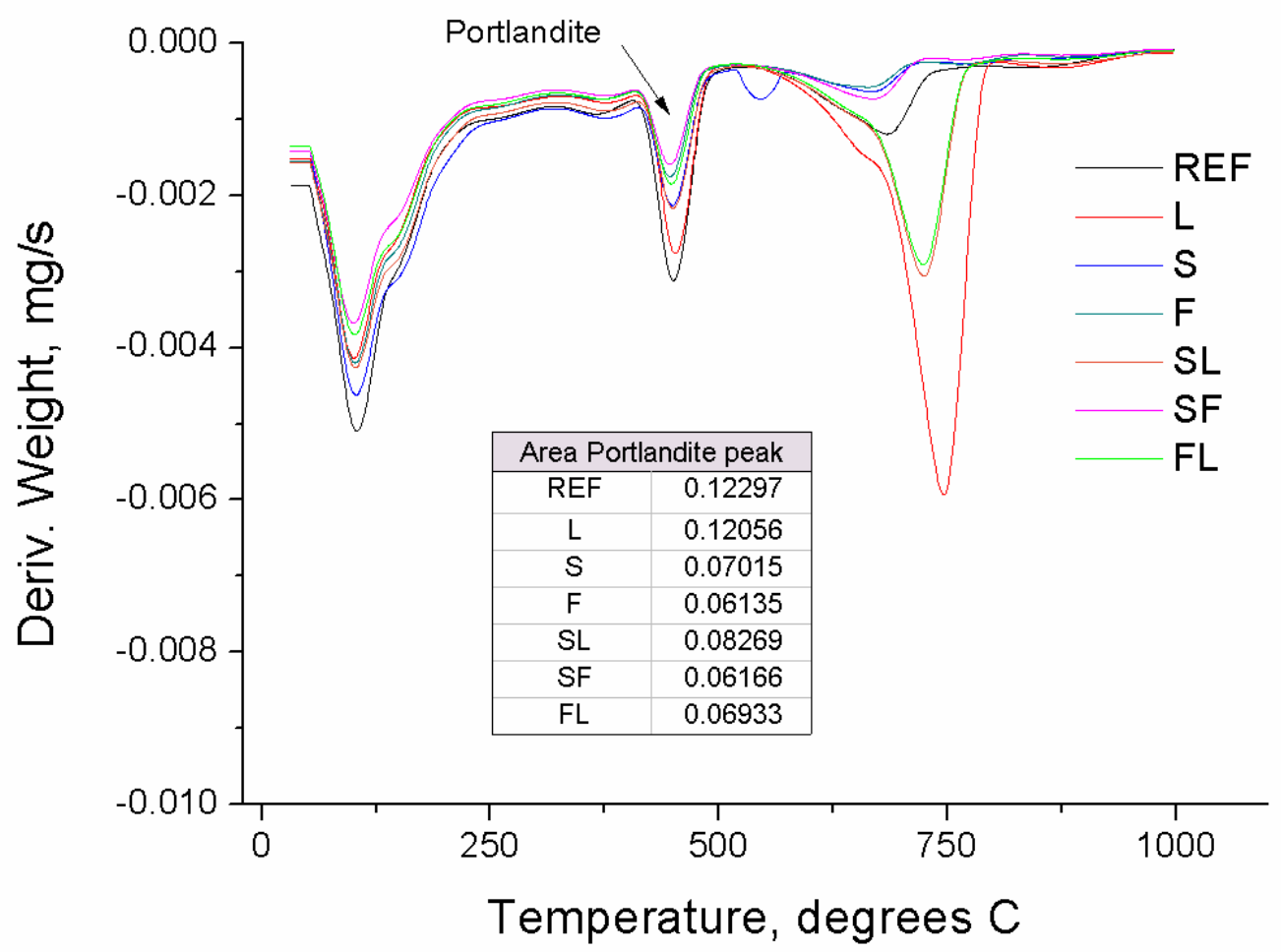

Figure 5. Derivate of weight versus temperature curves and areas of the portlandite peak obtained at 250 hardening days for different mortars analyzed.

$\square$ Absorption

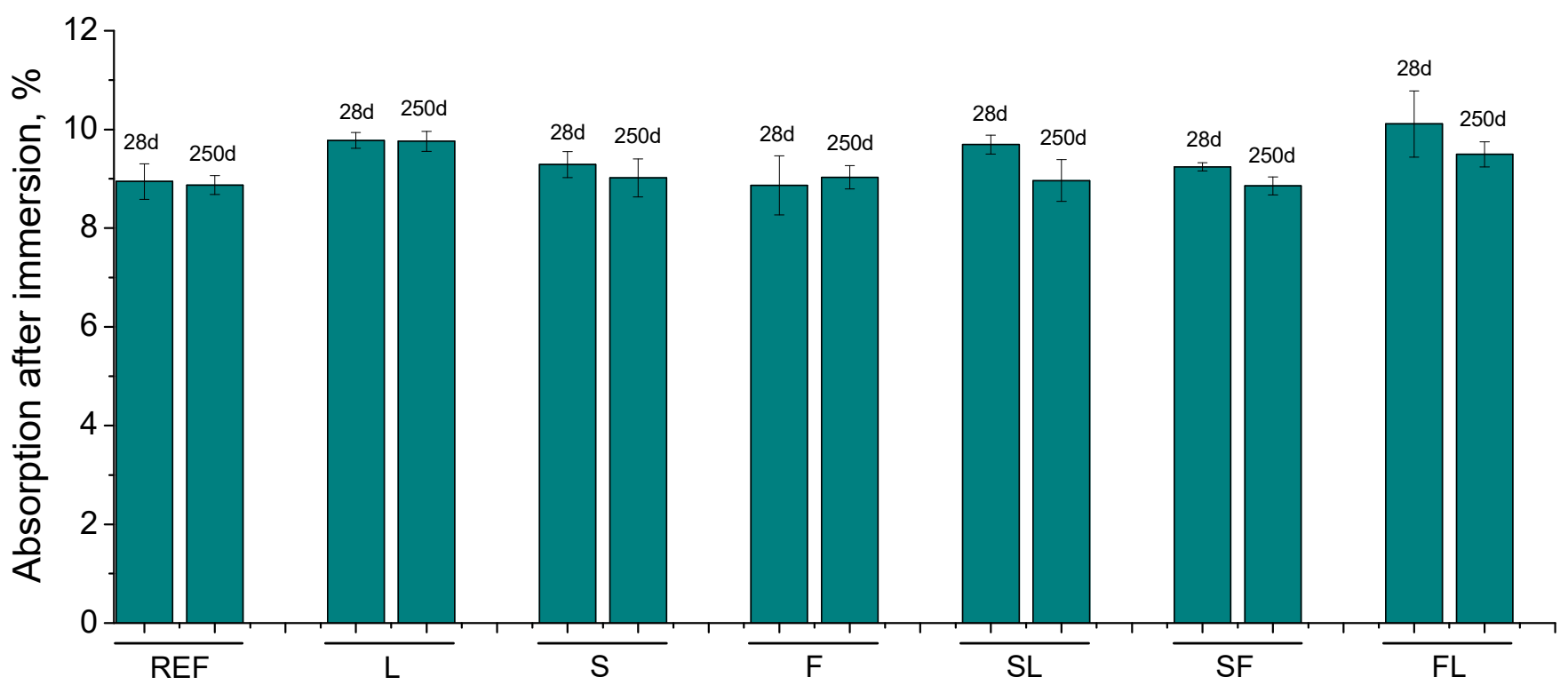

Figure 6. Results of absorption after immersion obtained for the analyzed mortars.

\subsection{Steady-State Chloride Diffusion Coefficient}

The results of the steady-state chloride diffusion coefficient obtained from the samples' resistivities for the analyzed mortars are represented in Figure 7. At 28 days, the lowest values of this parameter were observed for the REF mortars, followed by the $S$ ones. On the 
other hand, the highest values at that age corresponded to mortars prepared with binary binders with fly ash (F series) and limestone (L series). Regarding the specimens prepared with ternary binders, at 28 days, the SL and SF series showed lower diffusion coefficients compared to the FL mortars.

$\square$ Diffusion coef.

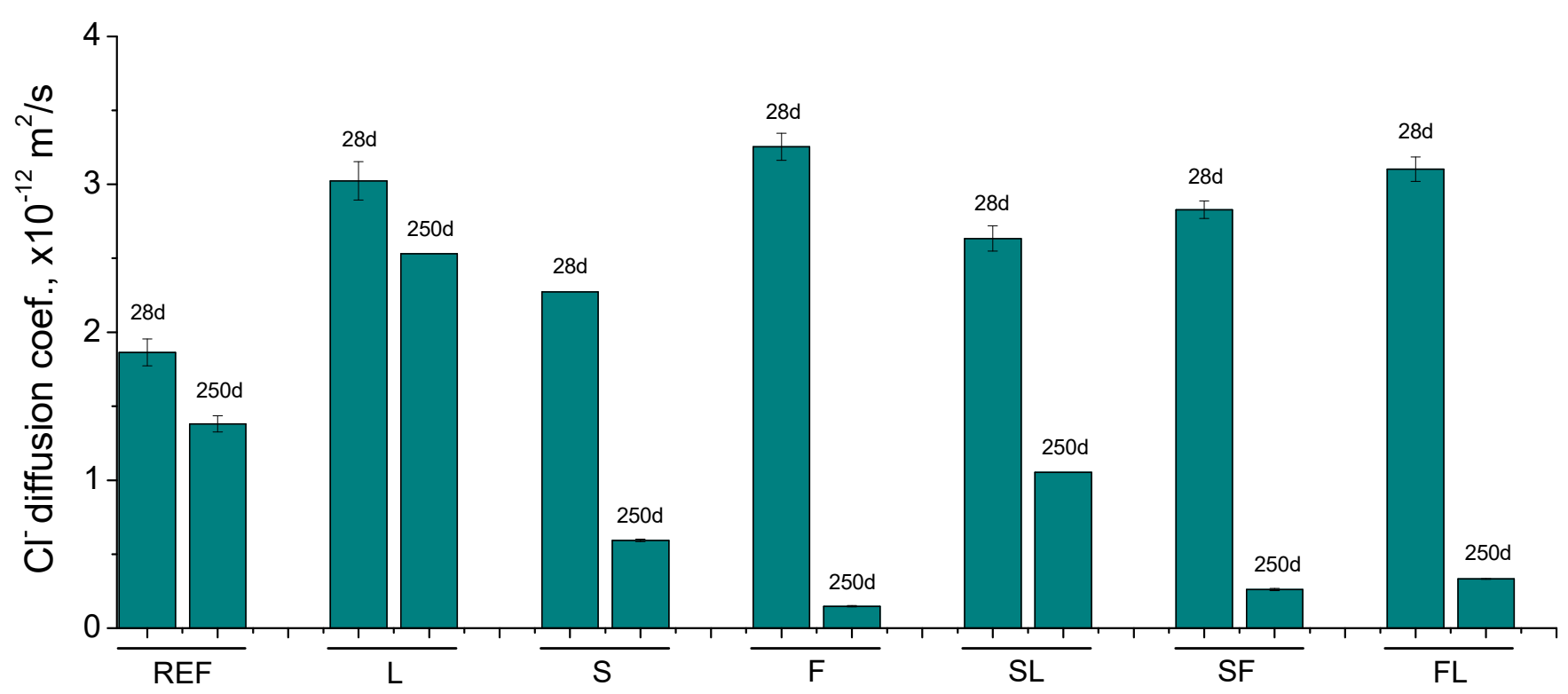

Figure 7. Steady-state chloride diffusion coefficient results noted for the studied binders.

It is interesting to highlight the noticeable reduction of the diffusion coefficient for mortars with active additions at 250 hardening days, especially for those which incorporated fly ash. At that age, the lower value of this parameter was noted for the F series, followed by the SF and FL series. The diffusion coefficient was higher for the S and SL mortars, compared to the abovementioned series with fly ash. Finally, the greatest value of this parameter at 250 days has been noted for the L mortars, followed by the REF ones.

\subsection{Mechanical Strengths}

The compressive strength results are depicted in Figure 8. At 28 days, the highest values of this parameter were noted for the REF and $S$ series, whereas the lowest were observed for the L mortars. In relation to mortars made using ternary binders, at the abovementioned age, the compressive strength was higher for the SF mortars, followed by the SL ones, while this parameter was slightly lower for the FL specimens. Between 28 and 250 days, the compressive strength increased for all the mortars studied. This increase was more noticeable for specimens prepared using binary and ternary binders with fly ash. At 250 days, the highest compressive strength values were observed for the REF, S, F and SF series, with slight differences between them, followed by the SL and FL binders. The lowest compressive strength at that age corresponded to the $\mathrm{L}$ series. 


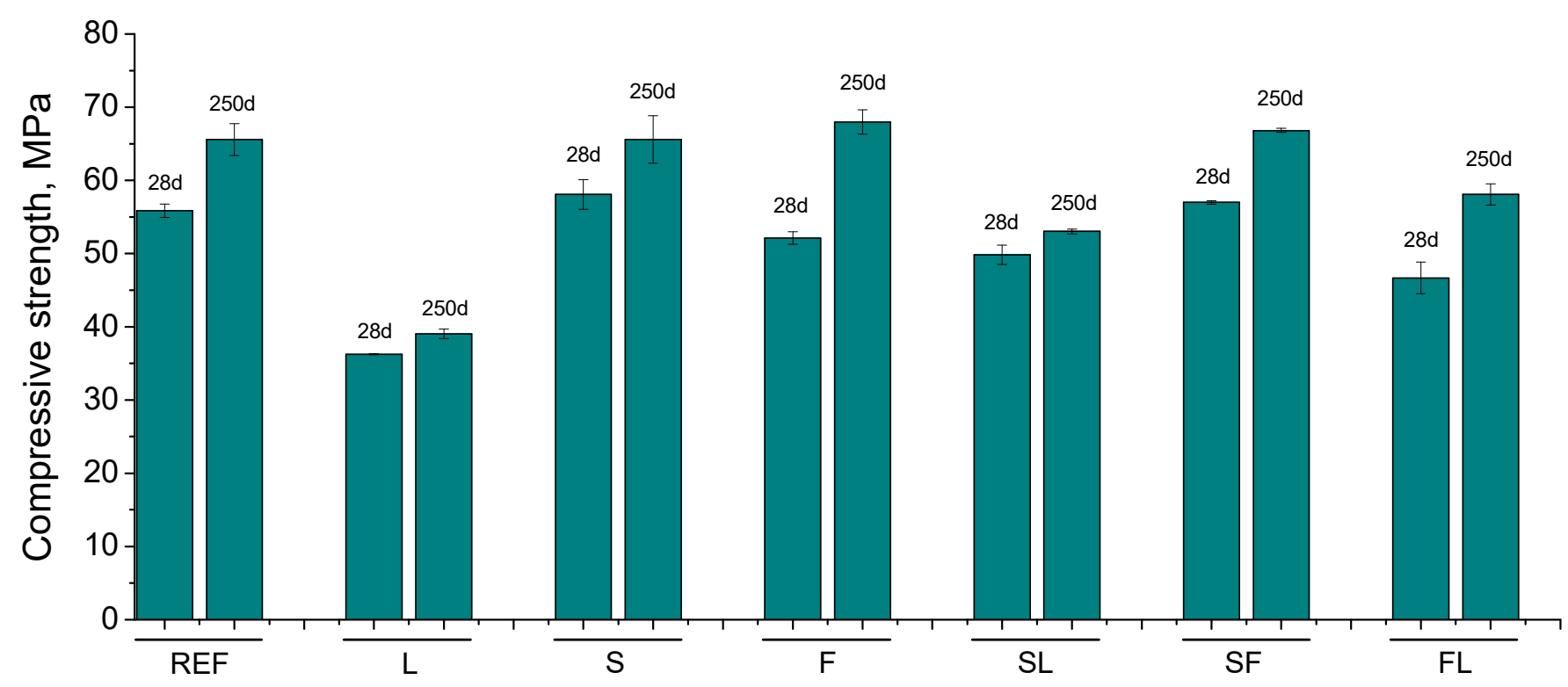

Figure 8. Compressive strength results for the different kinds of mortars tested.

The results of flexural strength are represented in Figure 9. The values of this parameter were relatively similar for all the studied mortars. At 28 hardening days, the flexural strength was slightly higher for the REF, S and SL mortars in comparison with the other series studied. This strength increased from 28 to 250 days for most of the analyzed mortars. After 250 hardening days, the highest flexural strengths were noted for the S and SL series, while the lowest were observed for the L and FL series.

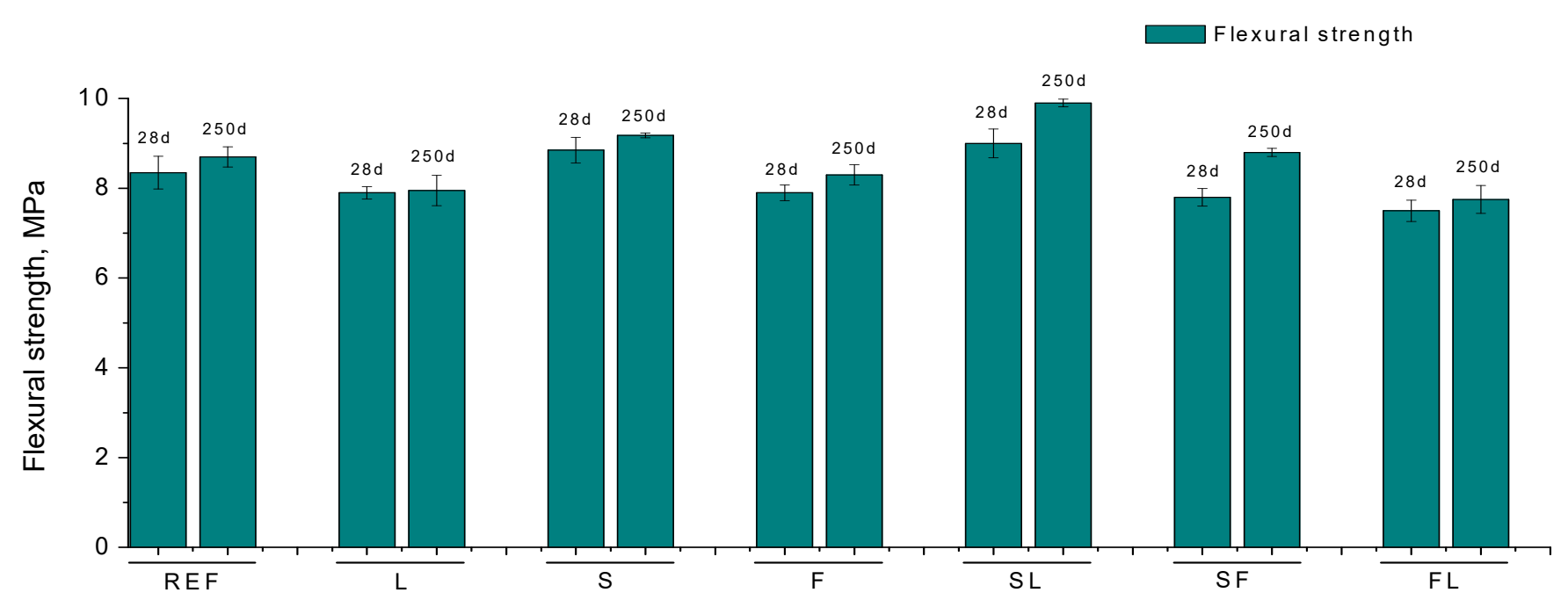

Figure 9. Flexural strength results observed for the analyzed binders.

\subsection{Ultrasonic Pulse Velocity}

The results of ultrasonic pulse velocity (UPV) can be observed in Figure 10. At initial ages, the lowest values of this parameter were observed for the L, SL and SF series, whereas the highest UPV values were noted for the reference mortars. In general, this parameter showed an increasing tendency with age for all the studied series. The UPV for mortars made with the binary binder with slag (S series) developed a noticeable growth up to approximately 28 days, and thereafter was the binder with the highest UPV values. For 
the binary binder with fly ash (F series), the UPV increase was slower, reaching similar values of this parameter compared to the $S$ series at 125 days, approximately. On the other hand, the main rise of this parameter was noted until 28 days for the reference mortars, slowly increasing since then until 250 days. With respect to mortars prepared using ternary binders, the UPV progressively rose with time, although with a slower rate compared to the $S$ series. The FL and SL mortars showed similar UPV values along the studied time period, being higher than the values noted for the SF mortars, compared to them. Finally, along the analyzed time period, the lowest UPV values were obtained for the L mortars.

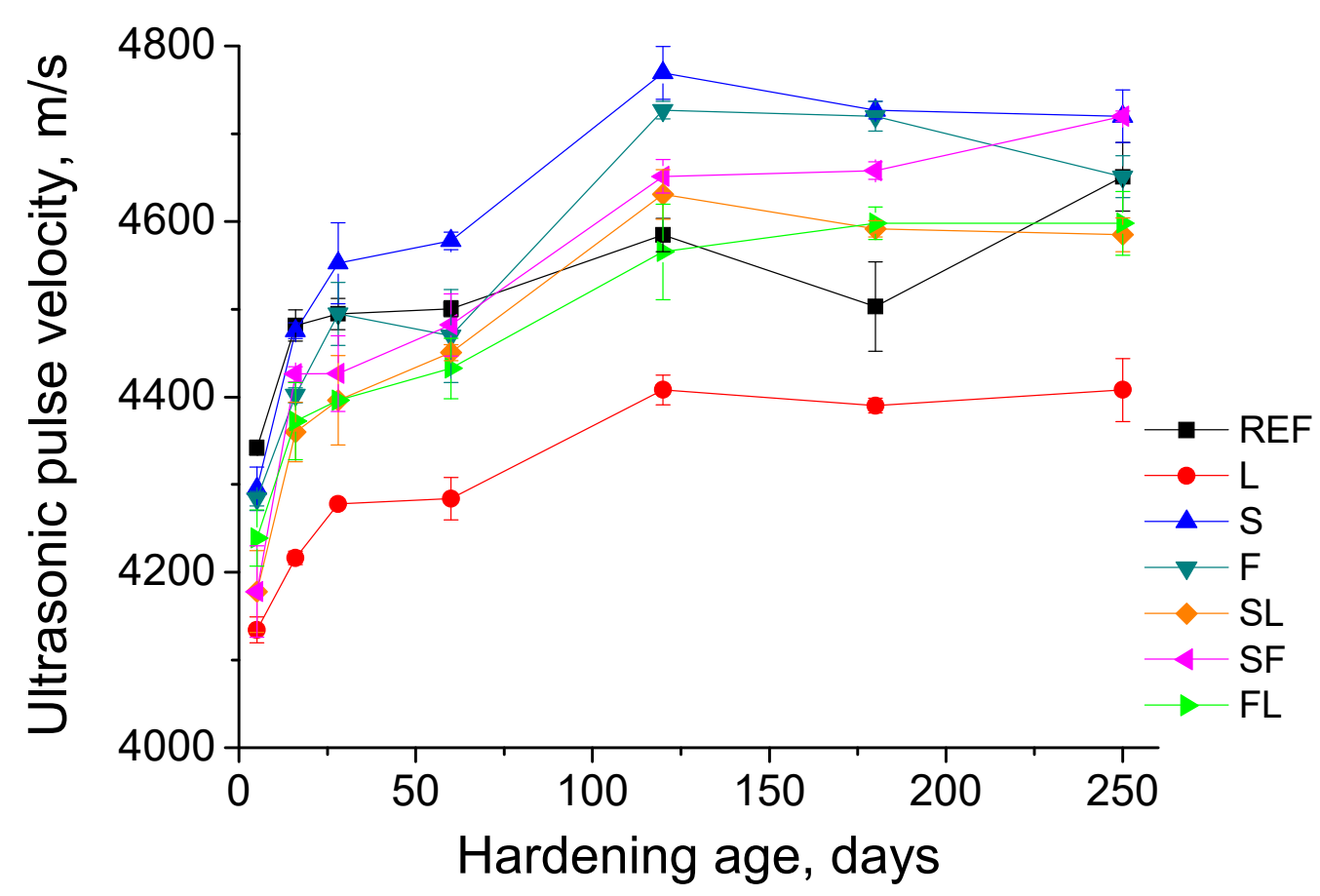

Figure 10. Evolution of ultrasonic pulse velocity for the types of mortars studied.

\section{Discussion}

\subsection{Microstructure Characterization}

Regarding mercury intrusion porosimetry results (see Figures 1 and 2), the lower total porosities noted at 28 days for the REF and S mortars are indicative of the development of slag and clinker hydration $[19,46]$, which started since setting, once both slag and clinker were in contact with water. This effect was more evident in these mortars because no other components apart from clinker or slag were present in them. The higher total porosity noted in the short term for $\mathrm{L}$ specimens could be explained by the fact the limestone acts as an inert filler material, without pozzolanic activity [47]. With respect to the F and FL binders, the larger porosities values at 28 days could be due to the delay of the development of fly ash pozzolanic reactions [15], compared to clinker and slag hydrations. The effect of this delay of fly ash pozzolanic reactions at short times can be also observed in the SF specimens, which showed higher porosity at that age, compared to binary binder with only slag ( $\mathrm{S}$ series). The mortars prepared with the ternary binder with slag and limestone (SL series) also showed higher total porosity at 28 days compared to the $\mathrm{S}$ specimens; this would be related to its lower content of an active addition with hydraulic activity such as slag and the presence of limestone as a filler inert addition [21,47].

With respect to the pore size distributions at 28 days, the higher percentage of finer pores noted for specimens with fly ash and ground granulated blast furnace slag in the binder would indicate a higher refinement of their microstructure, probably due to formation of solid phases as products of slag hydration $[19,46]$ and fly ash pozzolanic reactions [15]. This was especially noticeable for the SF binder, in which both the abovemen- 
tioned active additions were incorporated, being more evident the synergetic effects of both additions in the microstructure development. The less refined pore network noted for the L mortars would be in keeping with total porosity results, showing the effect of this not active addition.

The higher pore refinement noted for the majority of mortars studied at 250 days compared to 28 days would suggest the progressive closing of the microstructure due to the development of clinker and slag hydration [48-50], as well as fly ash pozzolanic reactions $[14,15]$. These reactions would produce new solid phases as products, entailing an increase of the relative volume of finer pores, as was observed in the pore size distributions. The fact that the increase of the proportion of finer pores from 28 to 250 days was more noticeable for mortars with only fly ash as active addition (F and FL series), could be related to the abovementioned delay of fly ash pozzolanic reactions $[15,51]$ in comparison with clinker and slag hydration, because these pozzolanic reactions need the presence of enough portlandite for starting them [15]. For the FL series, in its relatively high pore refinement it could have influenced the nucleation site effect of limestone addition, as has been reported by other authors [52]. The results of the area of portlandite peak (see Figures 4 and 5) would reveal the development of fly ash pozzolanic reactions from 28 to 250 days, as suggested by the portlandite consumption along this period of time, noted for binders with fly ash.

This delay in the development of these reactions would entail that the effects of fly ash in the microstructure would be observed at later ages [53], being in keeping with the results obtained. The long-term effects of the hydration of slag in binary and ternary binders were also noticeable, as suggest the more refined microstructure noted for them compared to reference mortars. Finally, the scarce effects with time in the total porosity produced by the incorporation of the studied additions in the binary and ternary binders, while they produced a refinement of the microstructure, would be in agreement with other works [9].

In relation to the electrical resistivity (see Figure 3), this parameter provides data about the connectivity of pores as well as the evolution of the microstructure [43]. The increasing tendency of this parameter for all the mortars studied would reveal the progressive development of their microstructure [54], due to a reduction of pores with higher diameters, as a consequence of the solid phases formation, as products of the abovementioned hydration and pozzolanic reactions of the different components of the studied binders [15,55]. This evolution with time of electrical resistivity would be in keeping with the progressive pore refinement observed in the pore size distributions already discussed. In addition, the higher values of this parameter overall observed for binary and ternary binders with slag and fly ash would also agree with the presence of a greater proportion of finer pores compared to the REF and L specimens, revealed by mercury intrusion porosimetry results.

Moreover, the higher values of electrical resistivity in the short term noted for binders with slag, especially for the $S$ series, would be probably due to the effects of slag hydration, which are more noticeable since early ages, due to the hydraulic activity of this addition [9], as has been explained for total porosity results. On the other hand, the slower rise with time, particularly at short ages, of the electrical resistivity for mortars with fly ash (F, FL and SF) would be indicative of the delay in the pozzolanic reactions development [15,56], already explained, also coinciding with the evolution of pore size distributions noted for these binders. Furthermore, the higher resistivity values at later ages for these binary and ternary binders with fly ash compared to the other analyzed mortars would suggest a greater presence of finer pores in their microstructure, being in agreement with their pore size distributions at 250 days.

\subsection{Durability and Mechanical Parameters}

With respect to durability-related parameters, the decrease with time of the steadystate chloride diffusion coefficient (see Figure 7) would be related to the progressive microstructure refinement produced by the development of slag and clinker hydration, and fly ash pozzolanic reactions, according to the previously discussed porosimetry results. 
At 28 days, the lower values of this parameter for the REF and S series and the higher values for binders with fly ash (F, FL and SF series) would again show the delay of fly ash pozzolanic reactions compared to slag and clinker, also coinciding with microstructural characterization.

However, the effects in the long term of fly ash were very noticeable in the diffusion coefficient, as showed the important reduction of this parameter between 28 and 250 days for the F, SF and FL series, even improving at the later studied age the values of this parameter noted for specimens with only slag as active addition. These results would be overall in keeping with the pore refinement in the long term produced by fly ash pozzolanic reactions, as suggested by the pore size distributions, electrical resistivity and differential thermal analysis results, already discussed. This pore refinement would make more difficult the diffusion of chlorides through the microstructure of the mortars, giving as results lower values of this coefficient.

The addition of slag in ternary and binary binders also produced a beneficial effect in this coefficient at 250 days, improving the reference mortars. This is due to the progressive development of slag hydration, which also produced a microstructure refinement, as has been previously explained for the mercury intrusion porosimetry results. For ternary binders with slag, it is interesting to highlight the good performance of SF mortars regarding the diffusion coefficient in the long term, probably produced by the combined effects of slag hydration and fly ash pozzolanic reactions. On the other hand, the fact that this parameter was slightly higher for SL mortars at 250 days could be due to the presence of limestone in the binder, an addition without pozzolanic or hydraulic activity. These effects were less noticeable when limestone was combined with fly ash in the binder (FL series), maybe due to the abovementioned influence of the pozzolanic reactions of this addition, as well as the nucleation site effect of limestone addition when it is combined with fly ash [52,57]. Finally, the reduction with time observed for the L and REF mortars would coincide with the increase of the presence of finer pores, revealed by pore size distributions, and it would be produced by clinker hydration development [46]. The highest diffusion coefficient in the long term for the L mortars would also agree with the previous results, and it would be due to the non-active effect of limestone addition [47].

The water absorption after immersion was similar for the different mortars studied (see Figure 6). With respect to the binders with active additions, at 28 hardening days, SL and FL specimens showed slightly higher values of this parameter compared to the $S, F$ and SF mortars, which would be produced by the addition of limestone in these binders, as has been already explained. However, in the long term the absorption after immersion decreased for mortars made with ternary binders, reaching approximately the values noted for the REF specimens. Therefore, the use of these binders did not produce a worsening in the behavior of the mortars in relation to this parameter.

Regarding the mechanical properties, the compressive strength results (see Figure 8) showed similarities with the microstructure characterization and diffusion coefficient results. The highest values of this strength at 28 days observed for the REF and S specimens, would be in keeping with their lower total porosities and lower diffusion coefficients noted at that age. As has been discussed, this could be due to the more noticeable effects at short ages of slag and clinker hydration $[19,46]$, compared to fly ash pozzolanic reactions. The compressive strength increased with age for all the studied mortars, this also agreed with the microstructure refinement and the reduction of diffusion coefficient with time observed, which would be produced as a consequence of the abovementioned reactions development. Again, the most considerable increase of compressive strength from 28 to 250 days was noted for mortars with fly ash (F, FL and SF), which would be in keeping with the rise of their relative volume of finer pores and with the noticeable reduction of their diffusion coefficient. Then, the effects of new solids formation as products of fly ash pozzolanic reactions would also have beneficial effects in the compressive strength of the mortars.

In relation to the ternary binders, it is worth to highlight the good compressive strength performance of SF mortars at 250 days, showing similar values as the REF mortars. This 
would show the synergetic effects in this parameter of incorporating two active additions, such as fly ash and slag, in the binder [58], which also happened for the diffusion coefficient. However, when one of both active additions was combined with limestone in the ternary binder (SL and FL series), the compressive strength showed lower values. This influence of the presence of limestone in the binder was more noticeable in compressive strength, compared to other parameters analyzed in this work [47]. As has been explained for the results previously discussed, this could be due to the fact the limestone is not an active addition [47], so its presence would not produce additional solids formation, which would progressively fill the pore network of the materials, improving their properties. This effect was more evident for binary binder with only limestone as addition (L series), which showed the lowest compressive strengths along the studied time period.

The differences between the different tested binders regarding the flexural strength were smaller (see Figure 9). However, there were similarities with the results of the previously analyzed parameters. On one hand, at 28 days, this strength was higher for the REF and S mortars, which was previously linked to the earlier development of slag and clinker hydration. On the other hand, for the majority of the binders studied, the flexural strength improved with age, in keeping with most of the previously discussed parameters.

The ultrasonic pulse velocity (UPV) is a useful parameter for getting data related to the mechanical performance of the material, as well the presence of defects and voids [45,59]. The lowest UPV values noted for the L mortars along the studied time period (see Figure 10) would suggest a worse mechanical behavior, which would agree with the lowest compressive strength values noted for this binder, as has been already explained. The increasing tendency of UPV for all the mortars would also be in keeping with the rise with time of compressive and flexural strengths observed. At initial ages, UPV was higher for the REF and $S$ mortars, highlighting the noticeable rise until 28 days for the $S$ mortars. This result again coincides with those discussed for other parameters, such as compressive strength, diffusion coefficient and total porosity, which were related to the early effects of clinker and slag hydration $[19,46]$.

The slower UPV growth with time noted for binary and ternary binders with fly ash was also in consonance with the results of the abovementioned parameters, showing the delay in the development of the pozzolanic reactions of this addition [15]. At later ages, the relatively high UPV values observed for the F, S and SF series would indicate that their microstructure would be more compact and their mechanical performance would be better in comparison with other analyzed mortars. This would be in agreement with microstructure characterization and compressive strength results, particularly showing the beneficial synergetic effects of combining fly ash and slag in the binder, being also in accordance with the adequate hardened properties of cement-based materials with ternary mixtures which incorporate both additions, reported by other authors [58]. Finally, the slightly lower values of UPV noted for the SL and FL series in the long term, compared to the F, S and SF series, would coincide with their lower compressive strengths, also revealing the effects of the addition of limestone in the reduction of the mechanical performance of the ternary mortars $[30,47]$.

\section{Conclusions}

In view of the results obtained, firstly it is important to highlight that the studied mortars showed a progressive refinement of their microstructure, as suggested by the rise with time of the relative volume of finer pores, revealed by mercury intrusion porosimetry results, and the increasing tendency of electrical resistivity. This pore refinement would be produced as a consequence of the development of slag and clinker hydration and fly ash pozzolanic reactions. Regarding the services properties, this microstructure refinement overall produced a reduction of the chloride diffusion coefficient and the enhancement of mechanical performance of the mortars.

Furthermore, at early ages, reference mortars without additions and mortars with slag generally presented lower porosities, lower diffusion coefficients, higher mechani- 
cal strength and higher ultrasonic pulse velocities, compared to specimens with fly ash. However, at later ages, mortars which incorporated fly ash in the binders showed a high pore refinement, a noticeable reduction of diffusion coefficient and an improvement of their mechanical properties. These results were related to the delay of fly ash pozzolanic reactions compared to slag and clinker hydration. This delay would be revealed by the differential thermal analysis performed, with the reduction of area of portlandite peak area from 28 to 250 days, noted for binders with fly ash.

Despite that, in general, the incorporation of slag and fly ash in the binary and ternary binders would produce a higher microstructure development and better durability and mechanical properties. This could be due to the effects of the hydraulic activity of slag and the pozzolanic activity of fly ash.

On the other hand, the highest total porosity, the lowest pore refinement, the lowest electrical resistivity, the highest diffusion coefficient, the smallest compressive strength and the lowest ultrasonic pulse velocity have been observed for binary mortars with only the addition of limestone. This could be explained in relation to the fact the limestone acts as an inert material, without hydraulic or pozzolanic activity, so its beneficial effects in the microstructure and properties development is limited compared to slag and fly ash.

Regarding the absorption after immersion parameter, it reached similar values in the long term for mortars made with ternary binders compared to reference specimens. Then, the use of these binders would not worsen the performance of the mortars regarding this parameter.

Finally, in relation to the ternary binders studied, in general the best performance was noted for the mortars which incorporated both slag and fly ash as additions (SF series), compared to those with limestone (SL and FL series). This would show the improvement of incorporating two active additions in the binder, produced by the combined synergetic effects of slag hydration and fly ash pozzolanic reactions. These effects were more noticeable regarding the compressive strength of the mortars.

Author Contributions: Conceptualization, J.M.O. and T.R.-H.; methodology, J.I.-G., J.M.O. and T.R.H.; investigation, J.I.-G., T.R.-H. and J.M.O.; data curation, J.I.-G. and J.M.O.; writing-original draft preparation, J.I.-G.; writing—review and editing, J.M.O.; supervision, J.M.O. and T.R.-H.; funding acquisition, J.M.O. The results included in this paper were obtained in the $\mathrm{PhD}$ thesis carried out by J.I.-G. at University of Alicante (Spain), under the supervision of J.M.O. and T.R.-H. All authors have read and agreed to the published version of the manuscript.

Funding: This work was supported by the Conselleria de Educación, Investigación, Cultura y Deporte (presently re-named as Conselleria de Innovación, Universidades, Ciencia y Sociedad Digital) de la Generalitat Valenciana, Spain (grant code GV/2019/070).

Institutional Review Board Statement: Not applicable.

Informed Consent Statement: Not applicable.

Data Availability Statement: Not applicable.

Acknowledgments: The authors wish to thank Cementos Portland Valderrivas S.A. for providing the ordinary Portland cement CEM I $42.5 \mathrm{R}$ and the limestone, fly ash and ground granulated blast furnace slag additions used in this study.

Conflicts of Interest: The authors declare no conflict of interest.

\section{References}

1. Benhelal, E.; Shamsaei, E.; Rashid, M.I. Challenges against $\mathrm{CO}_{2}$ abatement strategies in cement industry: A review. J. Environ. Sci. 2021, 104, 84-101. [CrossRef]

2. Zhang, C.-Y.; Yu, B.; Chen, J.-M.; Wei, Y.-M. Green transition pathways for cement industry in China. Resour. Conserv. Recycl. 2021, 166. [CrossRef]

3. Sergi, B.J.; Adams, P.J.; Adams, P.J.; Muller, N.Z.; Muller, N.Z.; Muller, N.Z.; Robinson, A.L.; Robinson, A.L.; Davis, S.J.; Davis, S.J.; et al. Optimizing Emissions Reductions from the U.S. Power Sector for Climate and Health Benefits. Environ. Sci. Technol. 2020, 54, 7513-7523. [CrossRef] 
4. Akbari, F.; Mahpour, A.; Ahadi, M.R. Evaluation of Energy Consumption and $\mathrm{CO}_{2}$ Emission Reduction Policies for Urban Transport with System Dynamics Approach. Environ. Model. Assess. 2020, 25, 505-520. [CrossRef]

5. Rodríguez, G.; Medina, C.; Alegre, F.J.; Asensio, E.; Sánchez de Rojas, M.I. Assessment of Construction and Demolition Waste plant management in Spain: In pursuit of sustainability and eco-efficiency. J. Clean. Prod. 2015, 90, 16-24. [CrossRef]

6. Coppola, L.; Bellezze, T.; Belli, A.; Bignozzi, M.C.; Bolzoni, F.; Brenna, A.; Cabrini, M.; Candamano, S.; Cappai, M.; Caputo, D.; et al. Binders alternative to Portland cement and waste management for sustainable construction-Part 1. J. Appl. Biomater. Funct. Mater. 2018, 16, 186-202. [CrossRef] [PubMed]

7. Valipour, M.; Shekarchi, M.; Arezoumandi, M. Chlorine diffusion resistivity of sustainable green concrete in harsh marine environments. J. Clean. Prod. 2017, 142, 4092-4100. [CrossRef]

8. Corinaldesi, V.; Moriconi, G. Influence of mineral additions on the performance of $100 \%$ recycled aggregate concrete. Constr. Build. Mater. 2009, 23, 2869-2876. [CrossRef]

9. Bijen, J. Benefits of slag and fly ash. Constr. Build. Mater. 1996, 10, 309-314. [CrossRef]

10. Demirboğa, R. Thermal conductivity and compressive strength of concrete incorporation with mineral admixtures. Build. Environ. 2007, 42, 2467-2471. [CrossRef]

11. Ganjian, E.; Pouya, H.S. The effect of Persian Gulf tidal zone exposure on durability of mixes containing silica fume and blast furnace slag. Constr. Build. Mater. 2009, 23, 644-652. [CrossRef]

12. Ortega, J.M.; Sánchez, I.; Climent, M.A. Influencia de diferentes condiciones de curado en la estructura porosa y en las propiedades a edades tempranas de morteros que contienen ceniza volante y escoria de alto horno. Mater. Construcción 2012, 63, 219-234. [CrossRef]

13. Ponikiewski, T.; Gołaszewski, J. The effect of high-calcium fly ash on selected properties of self-compacting concrete. Arch. Civ. Mech. Eng. 2014, 14, 455-465. [CrossRef]

14. Papadakis, V.G. Effect of fly ash on Portland cement systems. Cem. Concr. Res. 1999, 29, 1727-1736. [CrossRef]

15. Wang, A.; Zhang, C.; Sun, W. Fly ash effects. Cem. Concr. Res. 2004, 34, 2057-2060. [CrossRef]

16. Glinicki, M.; Jóźwiak-Niedźwiedzka, D.; Gibas, K.; Dąbrowski, M. Influence of Blended Cements with Calcareous Fly Ash on Chloride Ion Migration and Carbonation Resistance of Concrete for Durable Structures. Materials 2016, 9, 18. [CrossRef]

17. Chindaprasirt, P.; Kroehong, W.; Damrongwiriyanupap, N.; Suriyo, W.; Jaturapitakkul, C. Mechanical properties, chloride resistance and microstructure of Portland fly ash cement concrete containing high volume bagasse ash. J. Build. Eng. $2020,31$. [CrossRef]

18. Wedding, P.; Manmohan, D.; Mehta, P. Influence of Pozzolanic, Slag, and Chemical Admixtures on Pore Size Distribution and Permeability of Hardened Cement Pastes. Cem. Concr. Aggreg. 1981, 3, 63. [CrossRef]

19. Bouikni, A.; Swamy, R.N.; Bali, A. Durability properties of concrete containing $50 \%$ and $65 \%$ slag. Constr. Build. Mater. 2009, 23, 2836-2845. [CrossRef]

20. Ortega, J.M.; Sánchez, I.; Climent, M.A. Durability related transport properties of OPC and slag cement mortars hardened under different environmental conditions. Constr. Build. Mater. 2012, 27, 176-183. [CrossRef]

21. Dhandapani, Y.; Santhanam, M.; Kaladharan, G.; Ramanathan, S. Towards ternary binders involving limestone additions-A review. Cem. Concr. Res. 2021, 143. [CrossRef]

22. Hadji, T.; Guettala, S.; Quéneudec, M. Mix design of high performance concrete with different mineral additions. World J. Eng. 2021. [CrossRef]

23. Marchetti, G.; Irassar, E.F.; Rahhal, V.F. Effects of packing density and water film thickness on fresh and hardened properties of ternary cement pastes. Adv. Cem. Res. 2020, 32, 444-455. [CrossRef]

24. Cordeiro, G.C.; Toledo Filho, R.D.; Tavares, L.M.; Fairbairn, E.M.R. Experimental characterization of binary and ternary blendedcement concretes containing ultrafine residual rice husk and sugar cane bagasse ashes. Constr. Build. Mater. 2012, 29, 641-646. [CrossRef]

25. Radwan, M.K.H.; Onn, C.C.; Mo, K.H.; Yap, S.P.; Ng, C.G.; Yusoff, S. Eco-mechanical performance of binary and ternary cement blends containing fly ash and slag. Proc. Inst. Civ. Eng. Eng. Sustain. 2020, 174, 23-36. [CrossRef]

26. Bumanis, G.; Zorica, J.; Bajare, D. Properties of foamed lightweight high-performance phosphogypsum-based ternary system binder. Appl. Sci. 2020, 10, 6222. [CrossRef]

27. Dadsetan, S.; Bai, J. Mechanical and microstructural properties of self-compacting concrete blended with metakaolin, ground granulated blast-furnace slag and fly ash. Constr. Build. Mater. 2017, 146, 658-667. [CrossRef]

28. Ban, C.C.; Sern, L.J.; Jasme, N. The mechanical strength and drying shrinkage behavior of high performance concrete with blended mineral admixture. J. Teknol. 2019, 81, 59-67. [CrossRef]

29. Radlinski, M.; Olek, J. Investigation into the synergistic effects in ternary cementitious systems containing portland cement, fly ash and silica fume. Cem. Concr. Compos. 2012, 34, 451-459. [CrossRef]

30. De Weerdt, K.; Kjellsen, K.O.; Sellevold, E.; Justnes, H. Synergy between fly ash and limestone powder in ternary cements. Cem. Concr. Compos. 2011, 33, 30-38. [CrossRef]

31. AENOR UNE-EN 197-1:2011. Composición, Especificaciones y Criterios de Conformidad de los Cementos Comunes; Asociación Española de Normalización y Certificación: Madrid, Spain, 2011.

32. AENOR UNE-EN 196-1:2005. Métodos de Ensayo de Cementos. Parte 1: Determinación de Resistencias Mecánicas; Asociación Española de Normalización y Certificación: Madrid, Spain, 2005. 
33. Diamond, S. Mercury porosimetry. Cem. Concr. Res. 2000, 30, 1517-1525. [CrossRef]

34. Ouellet, S.; Bussière, B.; Aubertin, M.; Benzaazoua, M. Microstructural evolution of cemented paste backfill: Mercury intrusion porosimetry test results. Cem. Concr. Res. 2007, 37, 1654-1665. [CrossRef]

35. Horpibulsuk, S.; Rachan, R.; Chinkulkijniwat, A.; Raksachon, Y.; Suddeepong, A. Analysis of strength development in cementstabilized silty clay from microstructural considerations. Constr. Build. Mater. 2010, 24, 2011-2021. [CrossRef]

36. Pedeferri, P.; Bertolini, L. La Durabilità del Calcestruzzo Armato; Mc Graw-Hill Education: Milano, Italy, 2000; ISBN 9788838608452.

37. Ho, L.S.; Nakarai, K.; Duc, M.; Kouby, A.L.; Maachi, A.; Sasaki, T. Analysis of strength development in cement-treated soils under different curing conditions through microstructural and chemical investigations. Constr. Build. Mater. 2018, 166, 634-646. [CrossRef]

38. Polder, R.; Andrade, C.; Elsener, B.; Vennesland, Ø.; Gulikers, J.; Weidert, R.; Raupach, M. Test methods for on site measurement of resistivity of concrete. Mater. Struct. 2000, 33, 603-611. [CrossRef]

39. Lübeck, A.; Gastaldini, A.L.G.; Barin, D.S.; Siqueira, H.C. Compressive strength and electrical properties of concrete with white Portland cement and blast-furnace slag. Cem. Concr. Compos. 2012, 34, 392-399. [CrossRef]

40. AENOR UNE 83988-2:2014. Durabilidad del Hormigón. Métodos de Ensayo. Determinación de la Resistividad Eléctrica. Parte 2: Método de las Cuatro Puntas o de Wenner; Asociación Española de Normalización y Certificación: Madrid, Spain, 2014.

41. ASTM. ASTM C642-06 Standard Test Method for Density, Absorption, and Voids in Hardened Concrete; ASTM International: West Conshohocken, PA, USA, 2006; p. 3.

42. ASTM. ASTM C1202-12 Standard Test Method for Electrical Indication of Concretes Ability to Resist Chloride Ion Penetration; ASTM International: West Conshohocken, PA, USA, 2012.

43. Andrade, C.; Alonso, C.; Arteaga, A.; Tanner, P. Methodology based on the electrical resistivity for the calculation of reinforcement service life. In Proceedings of the 5th CANMET/ACI International Conference on Durability of Concrete, Supplementary Papers; Malhotra, V.M., Ed.; American Concrete Institute: Barcelona, Spain, 2000; pp. 899-915.

44. AENOR UNE-EN 1015-11:1999. Métodos de Ensayo de los Morteros Para Albañilería. Parte 11: Determinación de la Resistencia a Flexión y a Compresión del Mortero Endurecido; Asociación Española de Normalización y Certificación: Madrid, Spain, 1999.

45. AENOR UNE-EN 12504-4:2006. Ensayos de Hormigón en Estructuras. Parte 4: Determinación de la Velocidad de los Impulsos Ultrasónicos; Asociación Española de Normalización y Certificación: Madrid, Spain, 2006.

46. Ortega, J.M.; Sánchez, I.; Climent, M.A. Impedance spectroscopy study of the effect of environmental conditions in the microstructure development of OPC and slag cement mortars. Arch. Civ. Mech. Eng. 2015, 15. [CrossRef]

47. Meddah, M.S.; Lmbachiya, M.C.; Dhir, R.K. Potential use of binary and composite limestone cements in concrete production. Constr. Build. Mater. 2014, 58, 193-205. [CrossRef]

48. Duan, P.; Shui, Z.; Chen, W.; Shen, C. Effects of metakaolin, silica fume and slag on pore structure, interfacial transition zone and compressive strength of concrete. Constr. Build. Mater. 2013, 44, 1-6. [CrossRef]

49. Tsakiridis, P.E.; Agatzini-Leonardou, S.; Oustadakis, P. Red mud addition in the raw meal for the production of Portland cement clinker. J. Hazard. Mater. 2004, 116, 103-110. [CrossRef] [PubMed]

50. Çakır, Ö.; Aköz, F. Effect of curing conditions on the mortars with and without GGBFS. Constr. Build. Mater. 2008, 22, 308-314. [CrossRef]

51. Ortega, J.M.; Sánchez, I.; Climent, M.A. Impedance spectroscopy study of the effect of environmental conditions on the microstructure development of sustainable fly ash cement mortars. Materials 2017, 10, 1130. [CrossRef]

52. Mounanga, P.; Khokhar, M.I.A.; El Hachem, R.; Loukili, A. Improvement of the early-age reactivity of fly ash and blast furnace slag cementitious systems using limestone filler. Mater. Struct. Constr. 2011, 44, 437-453. [CrossRef]

53. Fernandez, A.; Alonso, M.C.; García-Calvo, J.L.; Lothenbach, B. Influence of the synergy between mineral additions and Portland cement in the physical-mechanical properties of ternary binders. Mater. Constr. 2016, 66. [CrossRef]

54. de Grazia, M.T.; Deda, H.; Sanchez, L.F.M. The influence of the binder type \& aggregate nature on the electrical resistivity of conventional concrete. J. Build. Eng. 2021, 43. [CrossRef]

55. Ortega, J.M.; Ferrandiz, V.; Antón, C.; Climent, M.A.; Sánchez, I. Influence of curing conditions on the mechanical properties and durability of cement mortars. In Materials Characterisation IV: Computational Methods and Experiments; Mammoli, A.A., Brebbia, C.A., Eds.; WIT Press: Southampton, UK, 2009; pp. 381-392. [CrossRef]

56. Chindaprasirt, P.; Jaturapitakkul, C.; Sinsiri, T. Effect of fly ash fineness on compressive strength and pore size of blended cement paste. Cem. Concr. Compos. 2005, 27, 425-428. [CrossRef]

57. De Weerdt, K.; Haha, M.B.; Le Saout, G.; Kjellsen, K.O.; Justnes, H.; Lothenbach, B. Hydration mechanisms of ternary Portland cements containing limestone powder and fly ash. Cem. Concr. Res. 2011, 41, 279-291. [CrossRef]

58. Hale, W.M.; Freyne, S.F.; Bush, T.D., Jr.; Russell, B.W. Properties of concrete mixtures containing slag cement and fly ash for use in transportation structures. Constr. Build. Mater. 2008, 22, 1990-2000. [CrossRef]

59. García-Vera, V.E.; Tenza-Abril, A.J.; Saval, J.M.; Lanzón, M. Influence of crystalline admixtures on the short-term behaviour of mortars exposed to sulphuric acid. Materials 2018, 12, 82. [CrossRef] 